\title{
Effect of Fermentation on the Nutritional and Antinutritional Composition of Lagenaria Siceraria Seeds
}

\author{
${ }^{1}$ Sani N. A., ${ }^{1}$ Hassan L. G., ${ }^{1}$ Dangoggo S. M., ${ }^{2}$ Ladan M. J., ${ }^{1}$ Ali-baba I. and \\ ${ }^{1}$ Umar, K.J. \\ ${ }^{I}$ Department of Pure and Applied Chemistry, Usmanu Danfodiyo University, Sokoto-Nigeria. \\ ${ }^{2}$ Department of Biochemistry, Usmanu Danfodiyo University, Sokoto-Nigeria.
}

\begin{abstract}
The dehulled seeds of three varieties of Lagenaria siceraria were subjected to control fermentation process. The fermented and unfermented seeds were analysed for their nutritional and anti-nutritional compositions using AOAC 1998. The fermented seeds were found to contain high amount of crude protein (48.12\%) and crude fibre (4.11\%) compared to $27.42 \%$ and $0.67 \%$ for unfermented seeds respectively. Similarly, crude lipid content of the seeds decreased by about 75\%. The process also results in decrease in phytate, oxalate, tannins and cyanide content with consequent increase in nitrate and Vitamin $C$. Hence fermenting the seeds is an important way of exposing its protein content and reducing the antinutritional content. The seeds were found to have good potentials for preparation of condiments which are commonly used in the preparation of soup.
\end{abstract}

Key words: Anti-nutritional, fermentation, Lagenaria, seed, nutritional

\section{Introduction}

Lagenaria siceraria is an annual climbing or crawling plant that is commonly cultivated in Northern Nigeria. It is called calabash gourd or bottle gourd in English, Gyandama in Hausa and Akeregbe in Yoruba. Members of this family consist of different varieties such as calabash, bottle gourd and calabash gourd and are widely used for ornamental purposes.

The plant bears fruit of different varieties and shapes as shown in plates 1-3. The numerous variations in shapes of these fruits are as a result of cross pollination of flowers of different species; this yields a different fruit with shape and size different from that of parent flowers [1] . This resulted into a dilemma on assigning scientific names to each variety; hence some of the varieties were called using local names of the geographical location of their origin. Its seeds are brown in colour, rectangular in shape and of variable size depending on the variety. They seed coat texture ranges from smooth in some varieties to those with marginal ridges [1,2].

Although researches have shown that many seeds such as those of Parkia biglobosa, Rhizopus oligosporus, Parkia roxburghii were fermented before being used in condiment preparation [3,4,5], L. siceraria seeds has not been documented for its use in fermentation.

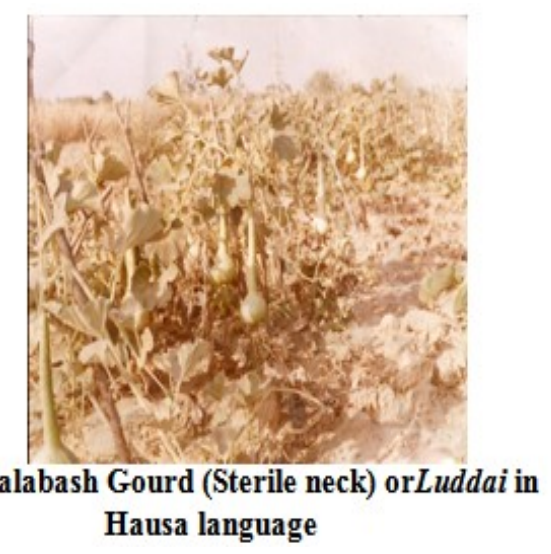

Plate 1.Calabash Gourd (Sterile neck) orLuddai in Hausa language

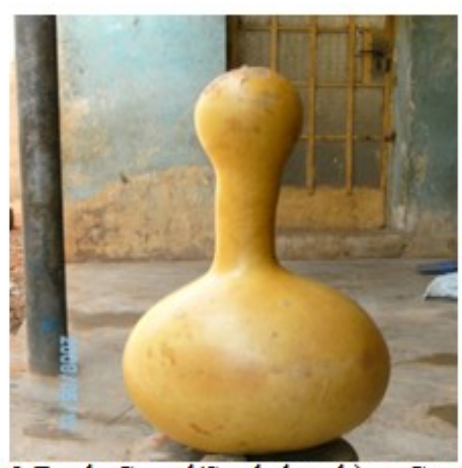

Plate 2.Bottle Gourd(Seeded neck) or Gyandama in Hausa language 


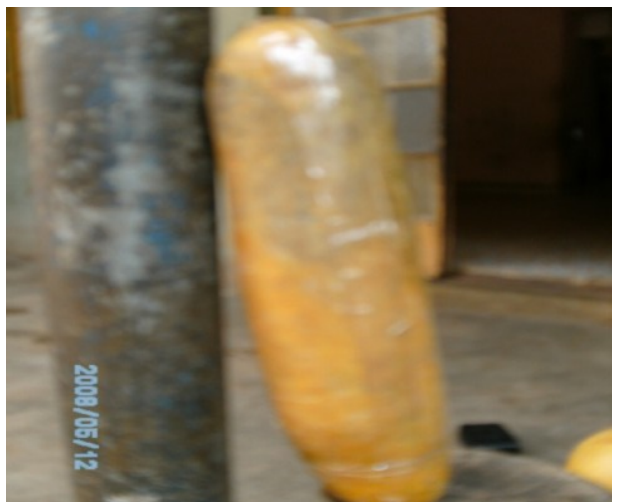

Plate 3. Elongated Calabash Gourd or Zungurum in Hausa language

The current work aimed at studying the effect of fermentation on the nutritional and antinutritional composition of raw and processed L. siceraria seeds.

\subsection{Sample collection and treatment}

\section{Materials and Method}

Lagenaria siceraria fruits were obtained from a farm land in Bukkuyum Local Government Area, Zamfara State, Nigeria. The fruits were identified at the Botany Unit, Department of Biological Sciences of Usmanu Danfodiyo University, Sokoto. The seeds were removed from the spongy pulp of the fruit, dried and dehulled manually. The dehulled seeds were kept pending the time for analysis.

\subsection{Fermentation process}

The seeds $(100 \mathrm{~g})$ were cooked for six hours (to softness) at $100^{\circ} \mathrm{C}$, covered in an airtight condition inside a pot for 24 hours, after which it was pounded, mixed with a solution of potash $(1 \mathrm{~g} / \mathrm{kg}$ of sample) to form a paste and fermented in an airtight condition at $31^{\circ} \mathrm{C}$ for 109 hours. The paste was air dried to a constant weight (this was to terminate the fermentation) and stored in a dark polythene bag prior to analysis.

The fermented and unfermented seeds were analysed for their residual moisture, ash, crude lipid, crude protein, crude fibre, and available carbohydrate contents [6]. Their phytate content was estimated using the method of Young and Greaves, [7], oxalate by Day and Underwood, [8] tannins by Allen et al.,[9], hydrocyanic acid by AOAC, [6].The nitrate and ascorbic acids were determined using IITA, [10] and AOAC, [6] respectively. The results obtained in each case were subjected to t-test using SPSS package.

\section{Result and Discussion}

Fig. 1-3 summerises the effect of fermentation on some nutrient composition of $L$. siceraria seeds. As seen in the charts, there was significant decrease in ash, lipid and available carbohydrate contents with consequent increase in residual moisture, crude protein and crude fibre contents of all the varieties.

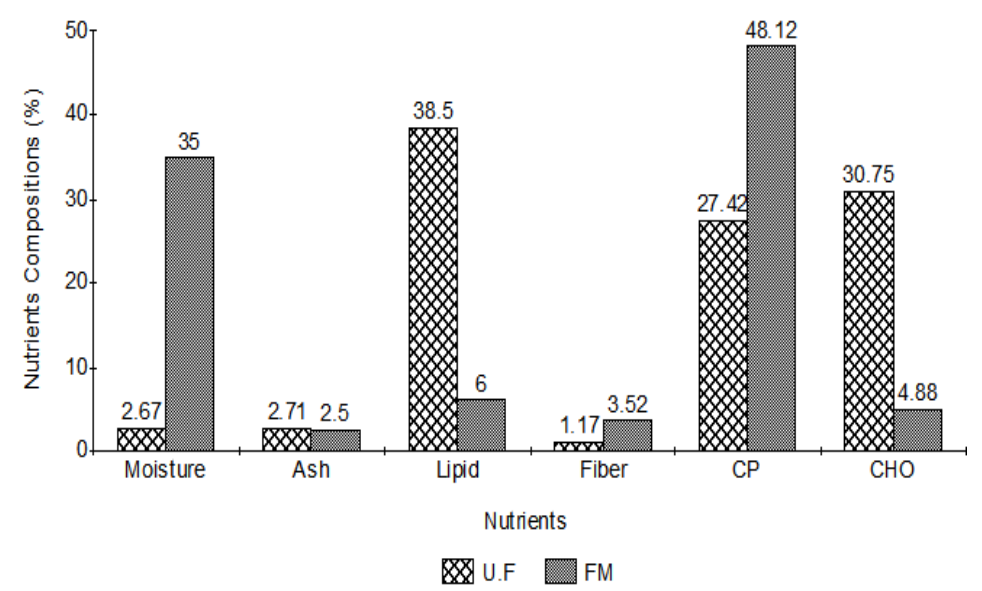

Figure 1: The Effect of Fermentation on the Proximate Composition of Luddai seed 
Key: U.F- Unfermented seed while F.M- fermented seed.

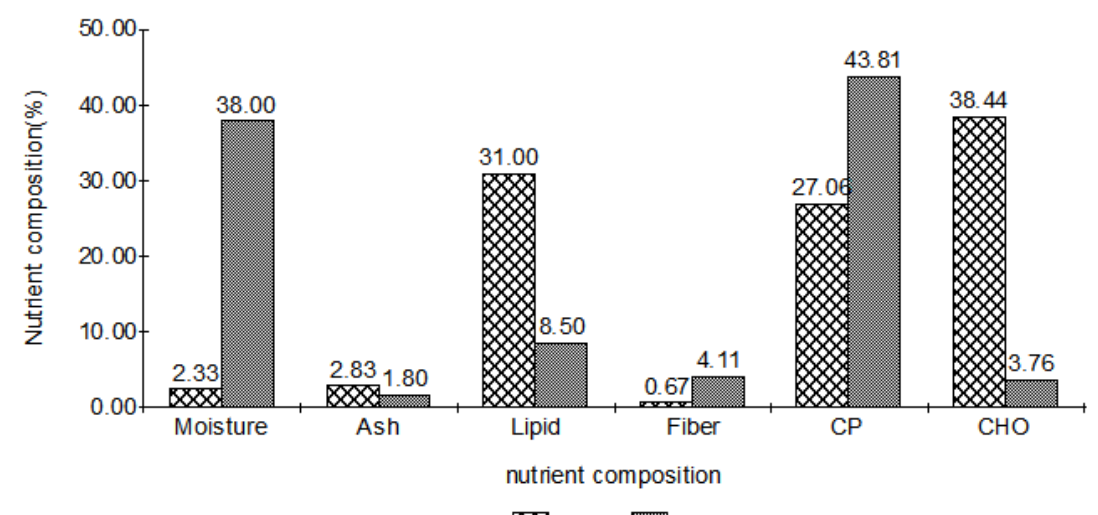

U.F $\square$ FM

Figure 2: The Effect of Fermentation on the Proximate Composition of Gyandama seed U.F stands for the unfermented seed while F.M represents fermented seed

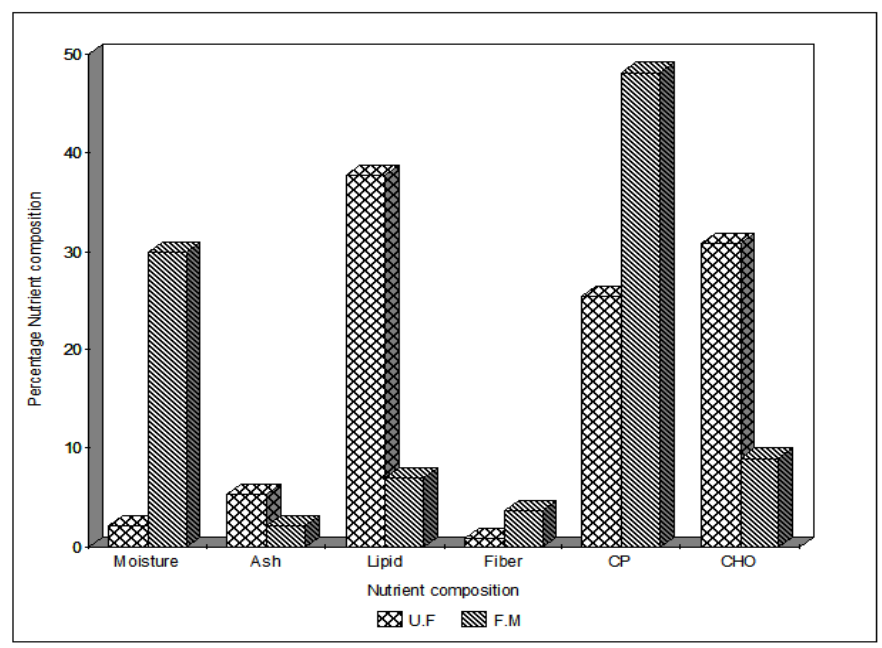

Figure 3: The Effect of Fermentation on the Proximate Composition of Zungurum seed U.F stands for the unfermented seed while F.M represents fermented seed.

Fig. 4-6 shows some antinutrient and antioxidant profile of L. siceraria seed. Phythate ranged between (9.88$11.11 \mathrm{mg} / \mathrm{g} ; 19.53-20.84 \mathrm{mg} / \mathrm{g})$, oxalate $(5.85-6.01 \mathrm{mg} / \mathrm{g} ; 6.45-7.05 \mathrm{mg} / \mathrm{g})$, Tannins $(4.81-5.52 \mathrm{mg} / \mathrm{g} ; 19.85-22.92$ $\mathrm{mg} / \mathrm{g})$, cyanide $\left(7.53 \times 10^{-5}-9.73 \times 10^{-5} \mathrm{mg} / \mathrm{g} ; 1.33 \times 10^{-4}-1.43 \times 10^{-4} \mathrm{mg} / \mathrm{g}\right)$, Nitrate $(400-412 \mathrm{mg} / \mathrm{g} ; 211-220 \mathrm{mg} / \mathrm{g})$ and Ascorbic acid (11.59-13 mg/g; 5.17-6.05 mg/g) for fermented and non fermented seeds respectively.

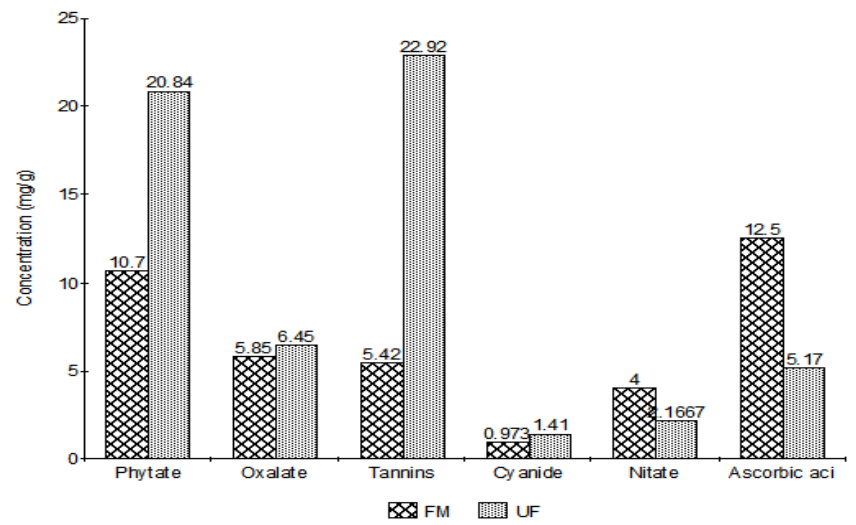

Figure 4: Some anti-nutrient and antioxidant contents of fermented and non-fermented Luddai seeds Note: Ascorbic acid and nitrate content are $x 10^{-5}$ and $10^{2}$ respectively. 


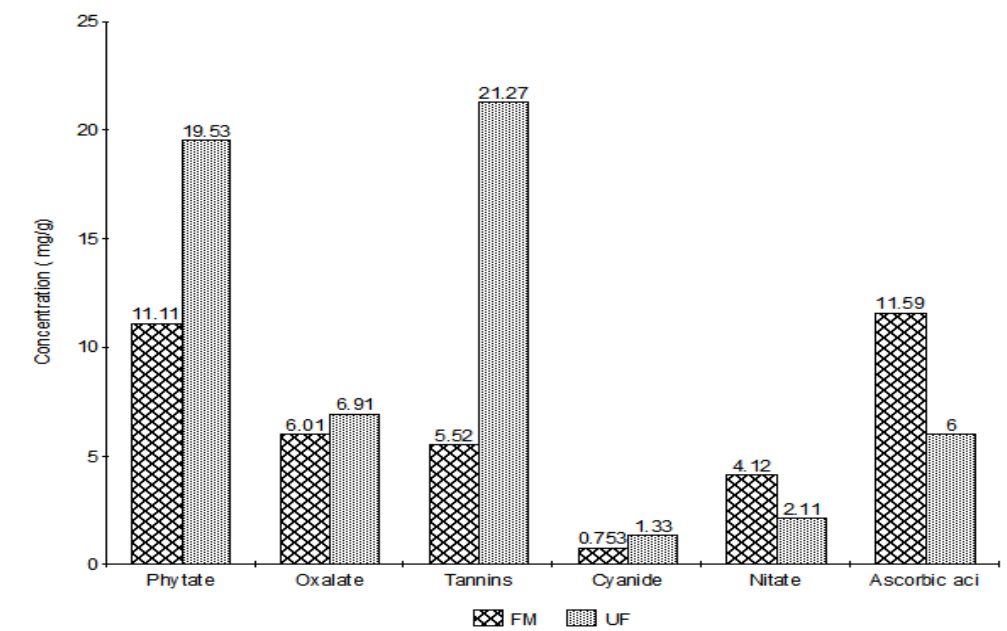

Figure 5 : Some anti-nutrient and antioxidant contents of fermented and non-fermented Gyandama seeds Note: Ascorbic acid and nitrate content are $\times 10^{-5}$ and $10^{2}$ respectively.

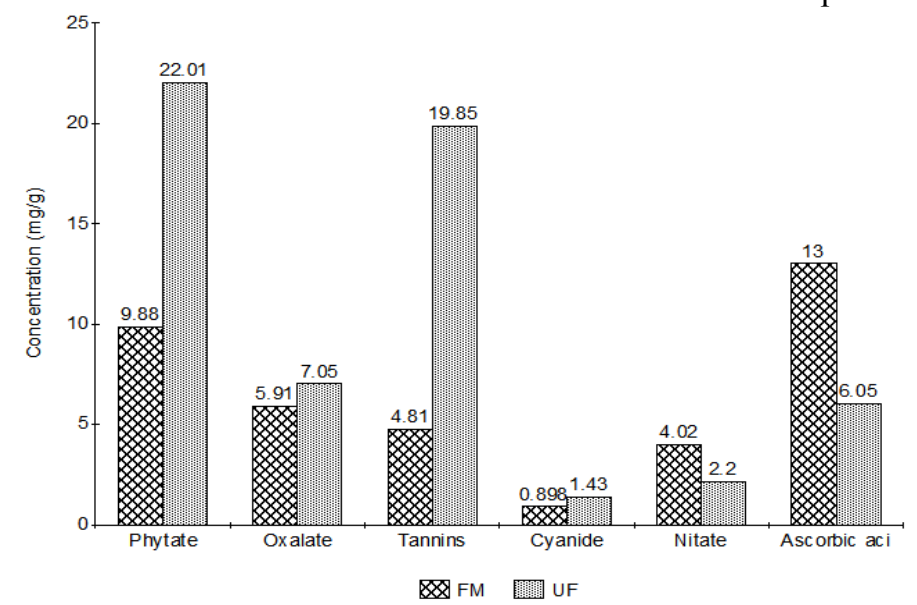

Figure 6: Some anti-nutrient and antioxidant contents of fermented and non-fermented Zungurum seeds Note: Ascorbic acid and nitrate content are $\mathrm{x} 10^{-5}$ and $10^{2}$ respectively.

\section{Discussion}

Moisture content of the fermented dehulled seeds are in the order Gyandama $>$ Ludddai $>$ Zungurum with values 38,35 and 30 respectively. The values are significantly high when compared with the residual moisture content of unfermented dehulled seeds 2.6, 2.3 and $2.17 \%$. The increase in the residual moisture content of the seed is due to boiling processes done during fermentation. This reduces the storage quality of seed when compared with the unfermented. High moisture content was also reported in fermented Banbra nut and African oil Bean[4,11].

The fermentation process has also shown significant impact on the ash content of the seed as seen in Fig. 1-3. Decrease in the ash content of fermented seed was in accordance with the observations of Fadahunsi and Sani [4]. This could be attributed to the drastic increase in protein and residual moisture content of the fermented seed which consequently lead to proportionate decrease in ash content. However, reduction in ash content of the seed contradicts the findings of Odebunmi et al, [5] on fermented locust bean seed.

Achinewu, 1986 observed no significant change in lipid content between fermented and unfermented African oil bean but only transformation of the saturated fatty acids to unsaturated ones. Similarly, Odebunmi et al., 2010 reported a significant increase in crude lipid content of pakia biglobosa seed from 19.30 to $35.27 \%$. However, in this research, there was a drastic reduction in the seed's crude lipid from $<40 \%$ to $6.0-8.5 \%$. This indicates that the organism used for the fermentation has in addition to sugar, utilized fatty acid as its source of energy. The result concurs with the findings of Fadahunsi and Sanni [4] on fermented Bambara nut seed.

The Protein content of the seed was found to almost doubled that of the unfermented seed. This could be attributed to the increase in microbial activity and protein hydrolysis [4]. This pre-digestion of protein is highly favourable as protein quality depends on both amino acid composition and availability[11,4]. In comparison with some food condiments such as locust bean (35.73\%), ginger (8.75\%) and garlic (7.87\%), it is apparent that, fermented $L$. siceraria seed is a better protein source for condiment preparation [5].

Carbohydrate and fibre content of the fermented seeds decreased sharply when compared with the unfermented seeds as seen in Fig. 4-6. This could be as the result of hydrolysis and subsequent utilization of 
sugar from the carbohydrate. The observed decrease is in agreement with the findings of Achinewu $[11\}$, Fadahunsi and Sanni [4] and Odebunmi et al., [5] who observed decrease of $27.7 \%$ and $27.8 \%$ for crude fibre and reducing sugar respectively. Hence, fermenting the seed would be a good way of reducing their carbohydrate content thus, making it relative safe for people requiring less sugar food.

There were significant difference in the results of the anti-nutrient components figure 4-6 of the fermented and non-fermented $L$. siceraria seeds respectively; phytate $(10.70 \pm 0.32$ and $20.84 \pm 0.72) \mathrm{mg} / \mathrm{g}$, oxalate $(5.85 \pm 0.45$ and $6.45 \pm 0.26) \mathrm{mg} / \mathrm{g}$, tannins $(5.41 \pm 0.14$ and $22.92 \pm 2.13) \mathrm{mg} / \mathrm{g}$ and cyanide $\left(9.73 \times 10^{-5} \pm 0.00\right.$ and $\left.1.41 \times 10^{-4} \pm 0.00\right) \mathrm{mg} / \mathrm{g}$.

Phytate content $(\mathrm{mg} / \mathrm{g})$ of fermented L. siceraria seed $(10.70 \pm 0.32)$ was significantly $(\mathrm{p}<0.05)$ lower than unfermented seed $(20.84 \pm 0.72)$ indicating $49 \%$ decrease due to fermentation. In comparison with phytate content of both fermented and unfermented $J$. curcas seed, L. siceraria has lower phytate content [12]. However, the percentage decrease in phytate content $(49 \%)$ is comparable to $(50 \%)$ obtained in the fermentation process of $J$. curcas seed. These observations are however contrary to the observations of Oladele and Oshodi [13] who observed an increase in the phytate and tannin content as a result of fermentation; but in consonance with what earlier obtained for reduced phytate by Oseni and Ekperigin [14] when pure strains of Aspergillus niger were used to ferment maize cobs, it is however possible that the mode of fermentation and the species of organisms involved play crucial roles in the fermentation processes. Decrease in phytate content due to fermentation will help in ensuring the bioavailability of minerals such as $\mathrm{Ca}, \mathrm{Mg}, \mathrm{Fe}$, and $\mathrm{Zn}$ [15].

The difference between the Oxalate content $(\mathrm{mg} / \mathrm{g})$ of fermented $(5.85 \pm 0.45)$ and non-fermented $(6.45 \pm 0.26)$ seeds is not significant $(\mathrm{p}<0.05)$. Oxalate content of both samples is quite low when compared with $10.31 \pm 1.00 \%$ reported for baobab seed [16]. On the other hand, the values obtained in this work are higher than $0.23,0.31,0.46$ and $0.56 \mathrm{mg} / \mathrm{g}$ reported for Artocarpus heterophyllus, Strychnos innocua, Bombax glabra, and Cola millenii seeds respectively [17]. Oxalate, when present in large quantity, chelates with some metal ions in the body, rendering them insoluble. Hence, cannot be absorbed in the intestine [18]. Thus, fermenting the seed would go a long way in solving the problem of nutrients mal-absorption.

Unfermented seeds are four times higher in tannin than fermented ones, indicating significant reduction in tanning content due to fermentation. The tannin content was higher than the range of $1.08-1.27 \mathrm{mg} / \mathrm{g}$ reported for some lesser known Nigerian seeds [17]. Conversely, the tannin content of the samples was lower than that of Baobab seeds with the values $2.84 \pm 0.30 \%[16]$.

Cyanide compositions (mg/g) of the samples were $9.73 \times 10^{-5} \pm 0.0$ and $1.41 \times 10^{-4} \pm 0.0$ for fermented and unfermented $L$. siceraria seeds respectively. The cyanide content in $\mathrm{mg} / \mathrm{g}$ of the non-fermented $L$. siceraria seed $\left(1.41 \times 10^{-4}\right)$ was very low compared to $5.1 \mathrm{mg} / \mathrm{g}$ obtained by Onweluzo and Nwabugwu [19] in their work on the fermentation of Millet (Pennisetum americanum) seeds for flour production. However, the effect of their fermentation is in agreement following the reduction in the cyanide content in both $\left(9.73 \times 10^{-5}\right.$ in $\mathrm{L}$. siceraria and 4.9 in Millet) by $31 \%$ and $4 \%$ respectively.

Generally, it has been established that fermentation results in decrease of phytate, tannin and oxalate contents of L. siceraria, J. curcas and P. americanum. Similarly, processing by fermentation, moist heating or any other heat treatment has also been reported to reduce anti-nutrients constituents of plant foods,[20]

Fig. 4-6 showed considerable difference in the nitrate content as a result of fermentation; $212.50 \pm 31.82$ and $400.00 \pm 318.20 \mathrm{mg} / \mathrm{g}$, for the non-fermented and fermented seed respectively (an increase of about $47 \%$ ).As a rule, $5 \mathrm{mg} / \mathrm{g} \mathrm{NO}_{3}$ on a dry matter basis is safe. Concentration of 5 to $10 \mathrm{mg} / \mathrm{g} \mathrm{NO}$ is considered potentially toxic. However, concentration above $10 \mathrm{mg} / \mathrm{g} \mathrm{NO}_{3}$ is considered dangerous [21]. This shows that the nitrate content of L. siceraria is too high but this could be as a result of accumulation of the nitrate which is usually triggered by some environmental stress, where plant growth is restricted but absorption of nitrate from the soil continues.

The result also showed that the seed contained $5.17 \pm 0.58 \mathrm{mg} / \mathrm{g}$ ascorbic acid. Although the quantity is appreciably large, fermentation almost tripled it to $12.50 \pm 3.37 \mathrm{mg} / \mathrm{g}$ (an increase of about $60 \%$ ). Ascorbic acid is needed for the growth and repair of tissues in all parts of our body. An average of $45,28,70,82.5 \mathrm{mg} / \mathrm{day}$ ascorbic acid is recommended for infants (0-12 months), children (1-13 years), adolescents (14-18 years) and adults (19 years and above) respectively [22].

\section{Conclusion}

In conclusion, the fermentation of $L$. siceraria seeds showed a significant increase in the crude protein, crude fibre and residual moisture suggesting it to have good potentials as protein source. Furthermore, fermentation also resulted in the significant reduction in the phytate, oxalate, tannins, and cyanide content with consequent increase in the nitrate and ascorbic acid contents. Hence, fermenting the seed could be a viable approach to reduction of the antinutritional content of the seed and also a method for the production of protein concentrate. 


\section{Reference}

[1]. Decker-Walter, D.S.; Wilkins-Ellert, S.M.; Staub, J.E. (2004). Discovery and genetic assessment of wild bottle gourd [Lagenaria siceraria (Mol.) Standley, Cucurbitaceae] from Zimbabwe. Econ. Bot., 58: 501-508.

[2]. Tsieri, M.M., Niamayoua, R.K., Mampouya, D., Silou, T.H., Tremolieres, A., Haron, S. and Tchapla, A. (2008): Comparative Study of Fatty Acid and Triglycerides of Luffa cylindrical Versus Cucurbitaceae Seeds Consumed in Congo Brazzaville. Pakistan Journal of Nutrition,7 (6): 733-740.

[3]. Hassan, L.G., Sani, N.A., Dangoggo, S.M. and Ladan, M.J. (2008): Nutitional Value of Bottle Gourd (Lagenaria siceraria) Seed, Global Journal of Pure and Applied Sciences, 14(3): 301-306.

[4]. Fadahunsi, I.F. and Sanni, A.I. (2010): Chemical and Biochemical Changes in Bambara Nut During Fermentation to 'Tempeh'. Electronic Journal of Environmental, Agricultural and Food Chemistry, 9(2):275-283.

[5]. Odebunmi, E.O., Oluwaniyi, O.O. and Bashiru, M.O. (2010): Comparative Proximate Analysis of Some Food Condiments. Journal of Applied Science Research, 6(3):272-274.

[6]. AOAC, (1998): Official Methods of Analysis, $16^{\text {th }}$ edition, Association of Official Analytical Chemists, Washington DC.

[7]. Young, S.M. and Greaves, J.S. (1940): Influence of Variety and Treatment of Phytic Acid Content of Wheat, Food Reseach,5:103105

[8]. Day, R.A, and Underwood, A.L. (1986). Quantitative Analysis. 5th ed. Prentice- Hall Publication.

[9]. Allen, E.S., Grimshaw, H.M., Parkinson, J.A. and Quarmby, C. (1974). Chemical Analysis of Ecological Materials. Blackwell Scientific Publication, London.

[10]. IITA (1988). Selected methods for soil and plant analysis (Manual series No.1).International Institute for Tropical Agriculture, Ibadan, Nigeria, pp. $55-56$.

[11]. Achinewhu, S.C. (1986): The Effect of Fermentation on Carbohydrate and Fatty Acid Composition of African Oil Bean Seed (Pentaclethra macrophylla), Food Chemistry 19:105-116.

[12]. Oseni, O.A. and Akindahunsi, A.A. (2011). Some Phytochemical Properties and Effect of Fermentation on the Seed of Jatropha curcas L. American Journal of Food Technology, 6: 158-165.

[13]. Oladele, E.P. and Oshodi, A.A. (2008). Effect of fermentation on some chemical and nutritive properties of berlandier nettle spurge (Jatropha cathartica) and physic nut (Jatropha curcas) seeds. Pak. J. Nutr., 7: 292-296.

[14]. Oseni, O.A. and Ekperigin, M. (2007). Studies on biochemical changes in maize wastes fermented with Aspergillus niger. Biokemistri, 19: 75-79.

[15]. Umar, K.J., Hassan, L.G., Dangoggo, S.M., Maigandi, S.A., and Sani, N.A. (2011): Nutritional and Anti-nutritional Profile of Spiny Amaranth (amaranthus viridis linn) Studia Universitatis "Vasile Goldiş", Seria Ştiinţele Vieţii 21(4): 727-737.

[16]. Nkafamiya, I. I., Osemeahon, S. A., Dahiru, D. and Umaru, H. A. (2007): Studies on the chemical composition and physicochemicalproperties of the seeds of baobab(Adasoniadigitata)African Journal of Biotechnology 6 (6):756-759,

[17]. Bello, M. O., Falade, O. S., Adewusi, S. R. and Olawore, N . O. (2008). Studies on the Chemical Compositions and Anti-nutrients of Some Lesser Known Nigeria Fruits. African Journal of Biotechnology,7(21): 3972-3979.

[18]. Ejikeme, P.M.,Obasi, L.N. and Egbuonu, A.C.C.(2010): Physicochemical and toxicological studies on Afzelia Africana seed and oil. African Journal of Biotechnology 9(13):1959-1963.

[19]. Onweluzo, J.C. and Nwabugwu, C.C. (2009) Fermentation of Millet (Pennisetum americanum) and Pigeon Pea(Cajanus cajan) Seeds for Flour Production:Effects on Composition and Selected Functional Properties. Pakistan Journal of Nutrition 8 (6): 737-744

[20]. Makkar, H.P.S. and Becker, K. (1999). Plant toxins and detoxification methods to improve feed quality of tropical seeds - Review. Asian-Aus. J. Anim. Sci., 12: 467-480.

[21]. Whittier J.C., (2011) Nitrate Poisoning, Professor, department of animal sciences, Colorado State University.

[22]. Vitamin C (2011) [Accessed on 23/10/2011]. Available from www.nlm.nih.gov/medlineplus/ency/article/002404.html 